\title{
THE GENUS COELOCRANIA AND THE \\ RESURRECTION OF THE GENUS PSEUDOSASTRA \\ (COLEOPTERA: CHRYSOMELIDAE: GALERUCINAE)
}

\author{
By Mohamed S. MohamedSAID \\ Centre for Insect Systematics \\ Universiti Kebangsaan Malaysia, \\ 43600 Bangi, Selangor, Malaysia
}

\begin{abstract}
The genus Coelocrania Jacoby is reviewed, with the resurrection of the genus Pseudosastra Jacoby. Four new species are herein described from Malaysia: Pseudosastra depressa, P. ghazallyi, $P$. indah, and P. latiffi. Keys to the species of Coelocrania and Pseudosastra are provided.
\end{abstract}

\section{INTRODUCTION}

Both the genera Coelocrania and Pseudosastra were erected by Jacoby, in 1886 and 1904, respectively. The type species for Coelocrania is Coelocrania terminata Jacoby (by monotypy). The type species for Pseudosastra is Sastra sulcicollis Jacoby (by monotypy). Maulik (1936) did not recognize Pseudosastra, but the species he described as Sastra dohertyi was transferred to the genus Pseudosastra by Aslam (1972). Wilcox (1975) also did not recognize Pseudosastra but synonymized it with Coelocrania, transferring Sastra dohertyi to Coelocrania. Recently, Shute (1983) transferred another of Maulik's species, Sastra rubya, to Coelocrania. Presently, Coelocrania is represented by six species (Wilcox, 1971, 1975; Shute, 1983).

The genus Coelocrania as recognized by Jacoby $(1886,1894)$, Wilcox $(1971,1975)$ and Shute $(1983)$ is the one with the frons concave and never forming a transverse ridge. In my opinion, this is not a distinctive character for it is also shared with several other genera. From the key to the genera of galerucine beetles of New Guinea provided by Shute (1983), there are ten genera having the frons without a transverse ridge.

Manuscript received 13 August 1993. 
This paper aims to resurrect the genus Pseudosastra Jacoby as a valid name as perceived by Jacoby (1904) and Aslam (1972). The following couplet separates the genus Coelocrania from Pseudosastra.

Elytra parallel-sided, elongate-oblong. Antennae robust, with first segment slightly longer than third. Posterior tarsus with the first segment not longer than segments 2 and 3 combined. Tarsal claws entirely appendiculate. New Guinea........Coelocrania Jacoby

Elytra rather pyriform, its lateral sides becoming broader in apical half. Antennae slender, with first segment shorter than third. Posterior tarsus with the first segment longer than segments 2 and 3 combined. Tarsal claws bifid, at least for the fore- and midtarsus. Oriental Region. Pseudosastra Jacoby

From the presently known six species under the genus Coelocrania, only two are retained and belong to the genus Coelocrania sensu stricto: Coelocrania terminata Jacoby and Coelocrania sulcicollis (Baly). The other four species are herein transferred to the genus Pseudosastra Jacoby.

For the past eight years of my collecting trips throughout Peninsular Malaysia and Borneo (Sabah and Sarawak), I could not find any specimen that can be considered to belong to the genus $\mathrm{Coe}$ locrania. What have been discovered are six species which belong to the genus Pseudosastra, including four herein described as new.

Holotypes are deposited in the Insect Collection, Centre for Insect Systematics, Universiti Kebangsaan Malaysia, Bangi (UKM). The following abbreviations are used in the text:

NMH The Natural History Museum, London.

MCZ Museum of Comparative Zoology, Harvard University, USA.

UKM Universiti Kebangsaan Malaysia, Bangi.

\section{SySTEMATICS}

\section{Coelocrania Jacoby}

Coelocrania Jacoby, 1886, Ann. Mus. Civ. Genova 24:120.1894, Novit. Zool., 1:307.- Wilcox, 1971, Coleopt. Cat. Suppl. Pars 78:67.- Shute, 1983, Bull. Br. Mus. Nat. Hist. (Ent.), 46:207, 
256. Type species: Coelocrania terminata Jacoby, examined, MCZ, Harvard University.

Key to the species of Coelocrania

1. Head brown, the interocular space 1.8 times as broad as the transverse diameter of each oculus. Pronotum entirely brown. Elytra brown, with apical one-fifth black. Length $8.4 \mathrm{~mm}$

terminata Jacoby

Head black, the interocular space as broad as the transverse diameter of each oculus. Pronotum black with basal border dark brown. Elytra brown, the apical one-half, with a narrow patch along the suture bluish black. Length $8.2 \mathrm{~mm}$ sulcicollis (Baly)

1.

Coelocrania terminata Jacoby

Coelocrania terminata Jacoby, 1886, Ann. Mus. Civ. Genova, 24:

120 (New Guinea). Type examined, MCZ.

2.

\section{Coelocrania sulcicollis (Baly)}

Atysa sulcicollis Baly, 1886, Trans. Ent. Soc. London, 1886: 32 (Malay Archipelago). Type examined, NHM.

Coelocrania sulcicollis: Wilcox, 1971, Coleopt. Cat. Suppl. Pars 78: 67.

Pseudosastra Jacoby, gen. rev.

Pseudosastra Jacoby, 1904, Ann. Mus. Civ. Genova, 41: 504.Aslam, 1972, J. Nat. Hist., 6: 501. Type species: Sastra sulcicollis Jacoby.

Key to the species of Pseudosastra

1. Sutural angle of elytron rounded ....................................

Sutural angle of elytron angulate ....................................6

2. Elytra entirely brownish or yellowish ................................3 Elytra with black markings, not entirely brownish or yellowish 
3. Head with the interocular space 1.8 times as broad as the transverse diameter of each oculus. Pronotum oblong, slightly broader than long. Ventral surface and legs dark brown. Length 5.5 mm (Burma) dohertyi (Maulik)

Head with the interocular space 0.8 times as broad as the transverse diameter of each oculus. Pronotum transverse, 1.5 times as broad as long. Ventral surface and legs yellowish. Length $5.5-6.0 \mathrm{~mm}$ malayana (Jacoby)

4. Elytron largely black, with median transverse band yellow. Head with the interocular space 1.2 times as broad as the transverse diameter of each oculus. Ventral surfaces of metathorax and abdomen black. Length $5 \mathrm{~mm}$ (Burma) rubya (Maulik)

Elytron largely brown, with black stripes.

5. Elytron yellowish, with two longitudinal black stripes, on lateral and sutural margins. Head with the interocular space 1.2 times as broad as the transverse diameter of each oculus. Pronotum oblong, 1.3 times as broad as long, broadest at apical one-third; posterior angles tuberculate. Length $6.5 \mathrm{~mm}$

indah Mohamedsaid, new species

Elytron with one longitudinal black stripe on lateral margin, sutural margin brownish. Head with the interocular space 0.75 times as broad as the transverse diameter of each oculus. Pronotum transverse, 1.6 times as broad as long, broadest at middle; posterior angles not tuberculate. Length $4.8 \mathrm{~mm}$

latiffi Mohamedsaid, new species

6. Pronotum transverse

Pronotum oblong 1.2 times as broad as long, broadest at middle, reddish brown, blackened on lateral margins. Head with interocular space 1.2 times as broad as the transverse diameter of each oculus. Anterior and middle legs brown, except tibiae black; posterior legs largely black. Length $6.0 \mathrm{~mm}$ .ghazallyi Mohamedsaid, new species

7. Ventral surface and legs generally yellowish or brownish. Head with the interocular space 1.2 times as broad as the trans- 
verse diameter of each oculus. Pronotum 1.6 times as broad as long, broadest at middle. Length $7.8 \mathrm{~mm}$.............sulcicollis (Jacoby)

Ventral surface and legs generally black. Head with the interocular space 1.4 times as broad as the transverse diameter of each oculus. Pronotum 1.8 times as broad as long, broadest at apical one-third. Length $6.5 \mathrm{~mm}$........depressa Mohamedsaid, new species

1. Pseudosastra depressa Mohamedsaid, n sp.

(Figs. 1, 7)

Head reddish brown, elongate, interocular space 1.4 times as broad as the transverse diameter of each oculus, longitudinal median furrow distinct from occiput to interantennal space; vertex smooth, almost impunctate; frontal tubercles elevated, subquadrate; vertex finely rugose; frons concave, sides convex, longer than antennal socket; maxillary palpi robust, apical segment conical, smaller than preceding segment. Eyes large, protuberant. Antennae brown, segments 1 club-shaped; 2 shortest, twice as long as broad; 3 longest, 2.3 times as long as 2, 1.2 times as long as 4; 5-7 shorter than 4, subequal in length; 8-10 shorter than 7, subequal in length; 11 longer than 10, pointed. Pronotum brown, shiny, glabrous, transverse, 1.8 times as broad as long; sides broadest at apical one-third; anterior and lateral borders margined; posterior border unmargined; anterior border straight, slightly sinuate in middle; primary setal pore tuberculate; surface broadly and very deeply depressed from apical one-third to the base. Scutellum triangular, pubescent. Elytron reddish brown; surface densely covered with pubescence and small punctures; sutural angle sharply curved and pointed. Ventral surface black. Legs black, except posterior tarsus dark brown; first segment of hind tarsus 1.7 times as long as 2 and 3 combined. Male apical sternite moderately deeply emarginate. Length $6.5-6.8 \mathrm{~mm}$.

Female. Unknown.

HOLOTYPE. Male, MALAYSIA, Pahang, Kuala Lompat, 31.i.1993, Salleh, Ismail. Ruslan (UKM).

PARATYPES. MALAYSIA, Pahang, Kuala Lompat, 24-26.v.1990, Zaidi, Ismail \& Ruslan, 1 male (UKM). MALAYSIA, Johor, Kukup, S. W. Johor, H. N. Ridley, 1908-199, 1 female (NHM). 
The new species resembles Pseudosastra sulcicollis (Jacoby), but differs in having the ventral surface and legs generally black and in the first segment of hind tarsus less than twice as long as segments 2 and 3 combined.

2. Pseudosastra ghazallyi Mohamedsaid, n. sp.

(Figs. 2, 8)

Head reddish brown, elongate, interocular space 1.2 times as broad as the transverse diameter of each oculus, longitudinal median furrow distinct from occiput to the anterior frons; vertex finely rugose; frontal tubercles elevated, subquadrate; frontoclypeus concave, sides convex, longer than antennal socket; maxillary palpi robust, apical segment conical, smaller than preceding segment. Eyes large, protuberant. Antennae yellowish, nearly twothirds of the body length; segment 1 club-shaped, shorter than 3; 2 shortest, twice as long as broad; 3 longest, 2.3 times as long as 2 , 1.2 times as long as $4 ; 5-8$ shorter than 4 , subequal in length; $9-10$ shorter than 8 , subequal in length; 11 longer than 10, pointed. Pronotum reddish brown, shiny, glabrous, oblong, 1.2 times as broad as long, broadest at middle; margins black; anterior and lateral borders margined, posterior border unmargined; anterior border broadly rounded anteriorly; primary setal pore tuberculate; surface broadly and deeply depressed from apical one-third to the base. Scutellum triangular, pubescent. Elytron reddish brown, blackened on sutural, lateral margins; sutural angle truncate; surface densely covered with pubescence and small punctures. Ventral surfaces of metathorax and abdomen black. Anterior and middle legs brown, except tibiae black; posterior legs entirely black; first segment of hind tarsus 1.2 times as long as 2 and 3 combined. Male apical sternite broadly and deeply emarginate. Length $6.0 \mathrm{~mm}$.

Female. Unknown.

HOLOTYPE. Male, MALAYSIA, Sabah, Lembah Danum, 3.iv.1989, Salleh, Ismail \& Nor (UKM).

PARATYPE. MALAYSIA, Sabah, Lembah Danum, 5.iv.1989, Salleh, Ismail \& Nor, 1 male (UKM).

The species name, ghazallyi, is named after Dr. Ghazally, former Chairman of the Danum Valley Management Committee, Sabah. 
The new species resembles Pseudosastra depressa, n. sp., but differs in having the sutural angle of elytron truncate, not sharply curved.

3. Pseudosastra indah Mohamedsaid, n. sp.

(Figs. 4, 10)

Head reddish brown, elongate, interocular space 1.2 times as broad as the transverse diameter of each oculus, longitudinal median furrow distinct from vertex to the anterior frons; vertex finely rugose, slightly depressed in middle; frontal tubercles elevated, subquadrate; fronto-clypeus concave, sides convex, longer than antennal socket; maxillary palpi robust, apical segment conical, smaller than preceding segment. Eyes large, protuberant. Antennae yellowish, nearly two-thirds of the body length; segment 1 club-shaped, shorter than $3 ; 2$ shortest, 2.5 times as long as broad; 3 longest, 2.5 times as long as $2,1.3$ times as long as $4 ; 5-7$ shorter than 4 , subequal in length; 8-10 shorter than 7 , subequal in length; 11 longer than 10, pointed. Pronotum reddish brown, shiny, glabrous, oblong 1.3 times as broad as long, broadest at apical onethird; anterior, lateral and posterior borders margined; anterior border straight; primary setal pore tuberculate; surface broadly and deeply depressed from apical one-third to base. Elytron yellowish, with two longitudinally black stripes, along sutural and lateral margins; sutural angle rounded; surface densely covered with pubescence and small punctures. Ventral surface black. Legs yellowish; first segment of hind tarsus 1.4 times as long as 2 and 3 combined. Male apical sternite broadly deeply emarginate. Length $6.5-6.8 \mathrm{~mm}$.

Female. Externally identical to male, except apical sternite entire. Length $6.5 \mathrm{~mm}$.

HOLOTYPE. Male, MALAYSIA, Sabah, Taman Kinabalu, 13-15.xii.1990, Zaidi, Ismail \& Ruslan (UKM).

PARATYPES. MALAYSIA, Sabah, Taman Kinabalu, 13-15.xii.1990, Zaidi, Ismail \& Ruslan, 2 females (UKM).

The species name, indah, is derived from a Malay word meaning beautiful. This is the most beautiful species of Pseudosastra.

The new species differs from other species of Pseudosastra by its distinctive elytron with two longitudinal black stripes on the yellowish background. 

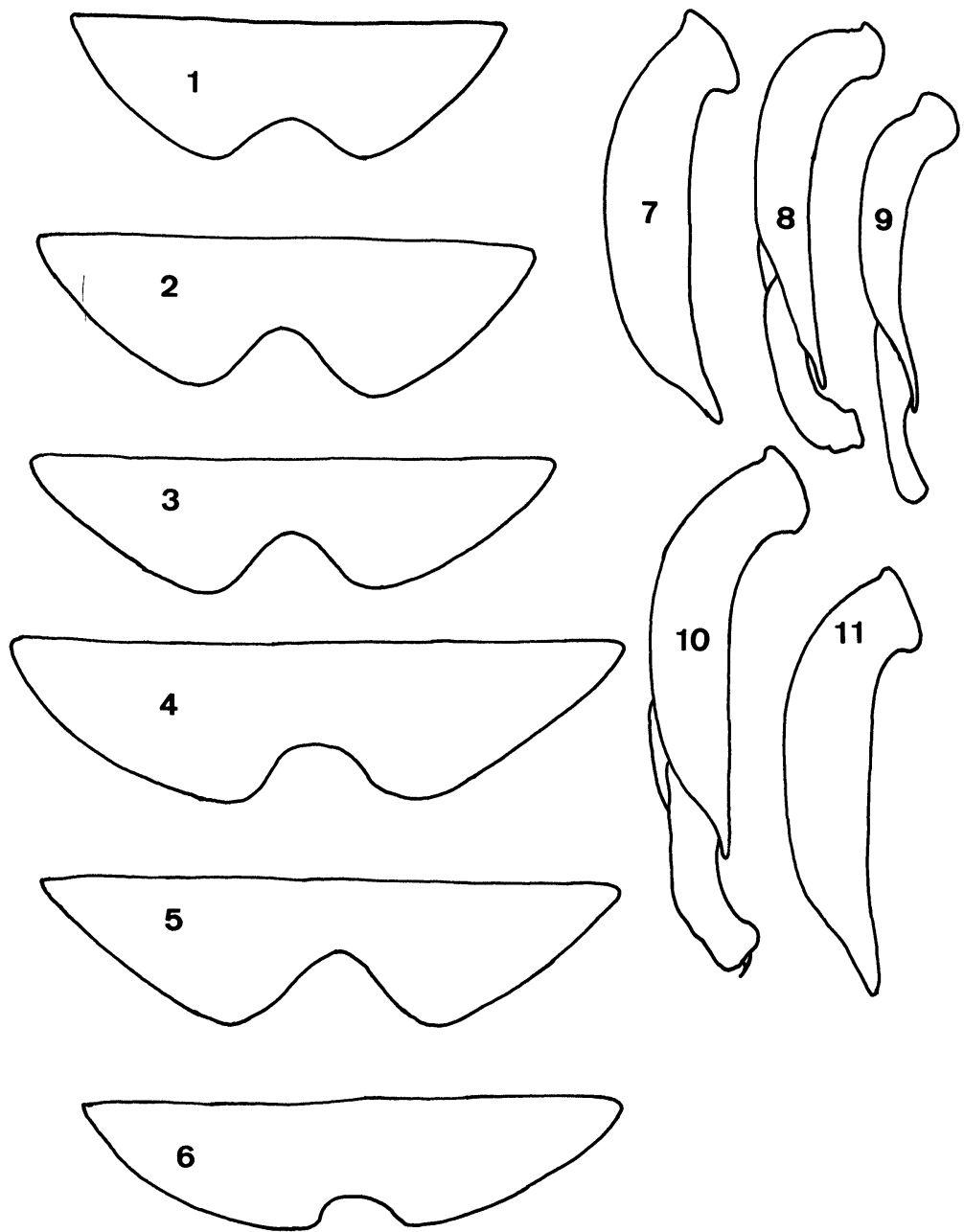

Figs. 1-6. Male apical sternite of Pseudosastra. 1. Pseudosastra depressa. 2. Pseudosastra ghazallyi. 3. Pseudosastra latiffi. 4. Pseudosastra indah. 5. Pseudosastra malayana. 6. Pseudosastra sulcicollis.

Figs. 7-11. Aedeagi of Pseudosastra, lateral view. 7. Pseudosastra depressa. 8. Pseudosastra ghazallyi. 9. Pseudosastra latiffi. 10. Pseudosastra indah. 11. Pseudosastra sulcicollis. 
4. Pseudosastra latiffi Mohamedsaid, n. sp.

(Figs. 3, 9)

Head brownish, elongate, interocular space 0.75 times as broad as the transverse diameter of each oculus, longitudinal median furrow distinct from occiput to the interantennal space; vertex rugose, with a triangular depression on each side of the longitudinal median furrow; frontal tubercles elevated, oblong; fronto-clypeus concave, sides convex, longer than antennal socket; maxillary palpi robust, apical segment conical, smaller than preceding segment. Eyes large, protuberant. Antennae extending two-thirds of body length, brownish, with apical segments blackened, nearly two-thirds of the body length; segment 1 club-shaped, shorter than 3; 2 shortest, twice as broad as long; 3 longest, 2.5 times as long as $2,1.5$ times as long as 4; 5-8 shorter than 4, subequal in length; 9-10 shorter than 8 , subequal in length; 11 longer than 10, pointed. Pronotum brown, shiny, glabrous, transverse, 1.6 times as broad as long, broadest at middle; anterior, lateral and posterior borders margined; anterior border straight; primary setal pore tuberculate; surface moderately deeply depressed from apical one-third to base. Scutellum oblong, pubescent. Elytron brown, with blackened areas on base and from humerus to apical one-fifth along lateral margin; sutural angle rounded; surface densely covered with pubescence and small punctures. Ventral surface dark brown. Legs brown; first segment of hind tarsus 1.5 times as long as 2 and 3 combined. Male apical sternite broadly and deeply emarginate. Length 4.8 $\mathrm{mm}$.

Female. Externally identical to male, except apical sternite entire. HOLOTYPE. Male, MALAYSIA, Pahang, Ekspedisi RompinEndau, 25-27.vii.1989, Salleh, Ismail \& Nor (UKM).

PARATYPES. MALAYSIA, Pahang, Kuala Lompat, 24-26.v.1990, Zaidi, Ismail \& Ruslan, 1 female; 18-20.viii.1990, Zaidi \& Ruslan, 1 male (UKM). Perak, Pondok Tanjung, 12.vi.1991, Ismail \& Yusuf, 1 male (UKM).

The species name, latiffi, is named after Dr. A. Latiff, Programme Leader of the IRPA Project No. 04-07-03-007.

The new species resembles Pseudosastra indah, n. sp., but differs in having the pronotum distinctly transverse, 1.6 times as broad as long. 
5. Pseudosastra malayana (Jacoby), comb. $\mathrm{n}$.

(Fig. 5)

Coelocrania malayana Jacoby, 1894, Novit. Zool., 1: 307 (Celebes). Cotype examined, MCZ, Harvard University.

Specimens examined. Malaysia, Terengganu, Jambu Bongkok, 22.ix.1991, Ismail, Yusuf \& Jainuddin, 3 (UKM).

Remarks. This is a new record for Malaysia.

6. Pseudosastra sulcicollis (Jacoby)

(Figs. 6, 11)

Sastra sulcicollis Jacoby, 1896, Ann. Mus. Civ. Genova, 36: 464 (Sumatra). Cotype examined, NHM, London.

Pseudosastra sulcicollis: Jacoby, 1904, Ann. Mus. Civ. Genova, 41: 504.

Coelocrania scolopaca Wilcox, 1971, Col. Cat. Suppl. Pars 78: 67 (new name for Sastra sulcicollis Jacoby, 1904, not Atysa sulcicollis Baly, 1886, both are Coelocrania).

Comments: Atysa sulcicollis Baly is neither an Atysa Baly nor a Pseudosastra Jacoby but a Coelocrania Jacoby. Atysa differs from both genera in having frons with a transverse ridge and the anterior coxal cavity closed behind. Atysa sulcicollis bears the characteristic of Coelocrania as provided in the couplet separating both genera (see Introduction).

The replacement name, Coelocrania scolopaca Wilcox, as proposed by Wilcox (1971) for Sastra sulcicollis Jacoby is no longer valid because Sastra sulcicollis is treated herein under Pseudosastra. Pseudosastra sulcicollis (Jacoby) as proposed by Jacoby (1904) is herein reinstated, although it was treated as a junior synonym by Wilcox (1971).

Specimens examined: MALAYSIA, Pahang, Kuala Lompat, 18-20.viii.1990, Zaidi \& Ruslan, 1 (UKM). Terengganu, Jambu Bongkok, 22.ix.1991, Ismail, Yusuf \& Jainuddin, 1 (UKM). Sarawak, Quop, W. Sarawak, G. E. Bryant, 23.iii.1914, 1 (NHM); 
Mt. Dulit. junction of rivers Tinjar \& Lejok, 15.ix.1932, native coll., 3 (NHM); Mt. Kalulong, 5.xi.1932, native coll., 1 (NHM); R. Kapah trib. of R. Tinjar, 3.x.1932, 1 (NHM); Tinjar \& Rumah Bulan Ding, 10.xi.1932, native coll., 1 (NHM); Mt. Matang, 1914, G. E. Bryant, 1 (NHM). Sabah, Poring, 9-12.xii.1990, Zaidi, Ismail \& Ruslan, 1 (UKM). INDONESIA, Sipora Island, West Sumatra, x.1924, C. B. K. \& N. S., 1 (NHM). Thailand, Peninsular Siam, Nakon Sri Tamarat, Khao Ram, 1500-2000 ft, 28.ii.1922, H. M. Pendlebury, 1 (NHM); Khao Luang, 2000 ft, 26.iii.1922, H. M. Pendlebury, 1 (NHM).

Remarks. This is a new record for Peninsula. Malaysia, Borneo and Thailand.

\section{ACKNOWLEDGMENTS}

The support of the grant from the IRPA Project No. 4-07-03007 for revisionary study on the Malaysian Chrysomelidae is gratefully acknowledged. Thanks go to the Chairman of the Danum Valley Management Committee, Sabah, for the permission to carry out field work in the Danum Valley Conservation Area. The author would also like to thank Ms. S. L. Shute, Natural History Museum (NHM), London, for the permission to examine type specimens; the Ernst Mayr Grant Committee for providing funds to enable him to visit Museum of Comparative Zoology (MCZ), Harvard University, USA; and Dr. John A. Wilcox, Lancaster, Ohio, USA, for his willingness to discuss with the author about Galerucinae during his visit to Lancaster in May 1993. The resurrection of the genus Pseudosastra was one of the subjects discussed.

\section{REFERENCES}

AsLam, N. A.

1972. On the genus Drasa Poryant (Coleoptera, Chrysomelidae, Galerucinae) with some nomenclatorial notes on the Galerucinae. Jour. Nat. Hist. 6(5): 483-501.

BALY, J. S.

1886. Descriptions of new genera and species of Galerucidae. Trans. Ent. Soc. London 1886(1): 27-39.

JACOBY, M.

1886. Description of new genera and species of phytophagous Coleoptera from Indo-Malayan and Austro-Malayan sub-regions, contained in the Genoa Divic Museum. Ann. Mus. Civ. Genova 4: 41-128. 
JACOBY, M. (CONT.)

1894. Description of new genera and species of phytophagous Coleoptera obtained by W. Doherty in the Malayan Archipelago. Nov. Zool. 1: 267-330.

1904. Descriptions of new genera and species of phytophagous Coleoptera obtained by Dr. Loria in New Guinea. Ann. Mus. Civ. Genoa 41: 498-504.

MAULIK, S.

1936. The Fauna of British India, including Ceylon and Burma. Coleoptera, Chrysomelidae, Galerucinae. Francis \& Taylor, London.

SHUTE, S. L.

1983. Key to the genera of galerucine beetles of New Guinea, with a review of Sastra and related new taxa (Chrysomelidae). Bull. Br. Mus. Nat. Hist. (Ent.) 46(3): 205-266.

WiLcox, J. A.

1971-1975. Coleopterorum Catalogus, supplementa Pars 78(1-4): 1-770. 

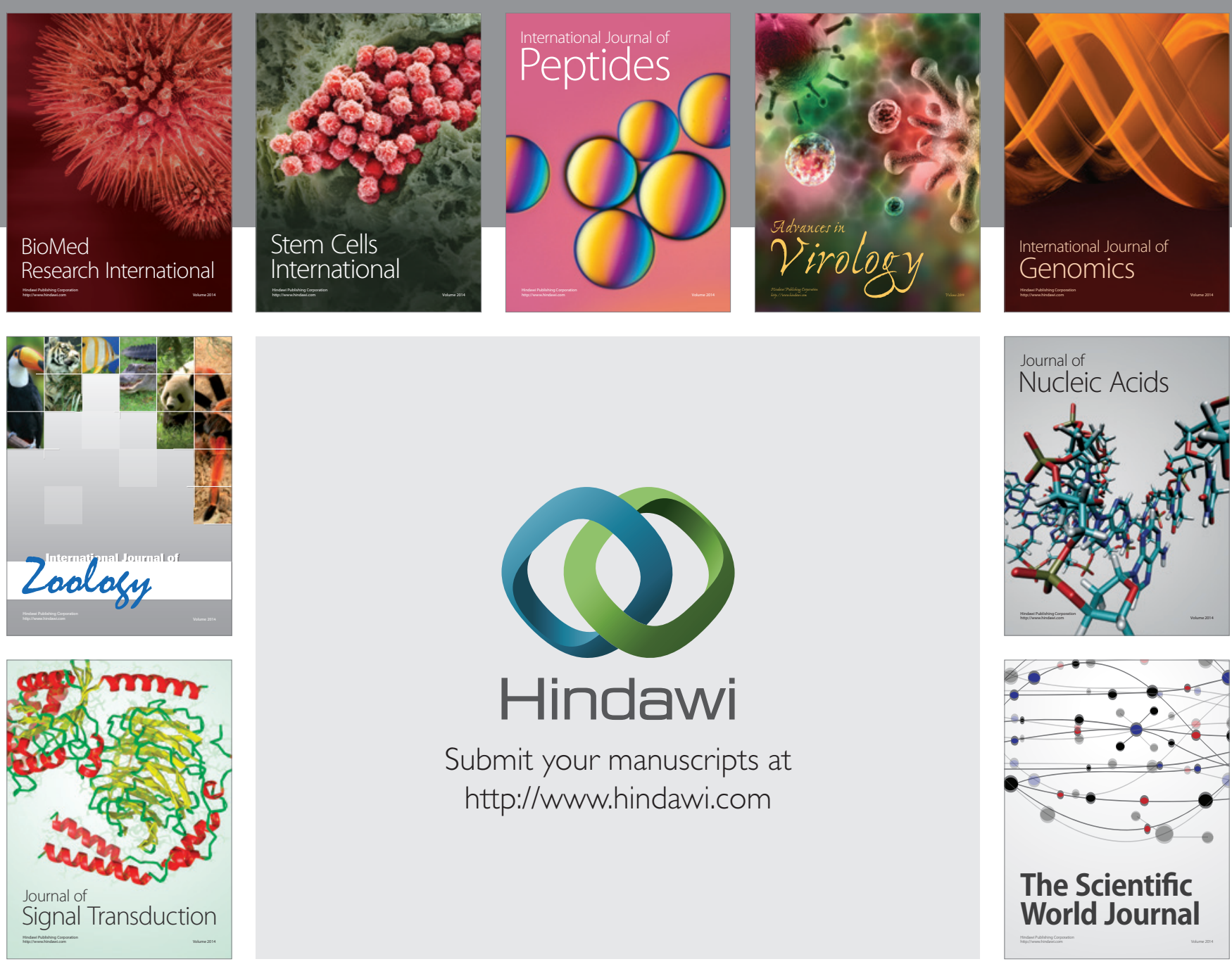

Submit your manuscripts at

http://www.hindawi.com
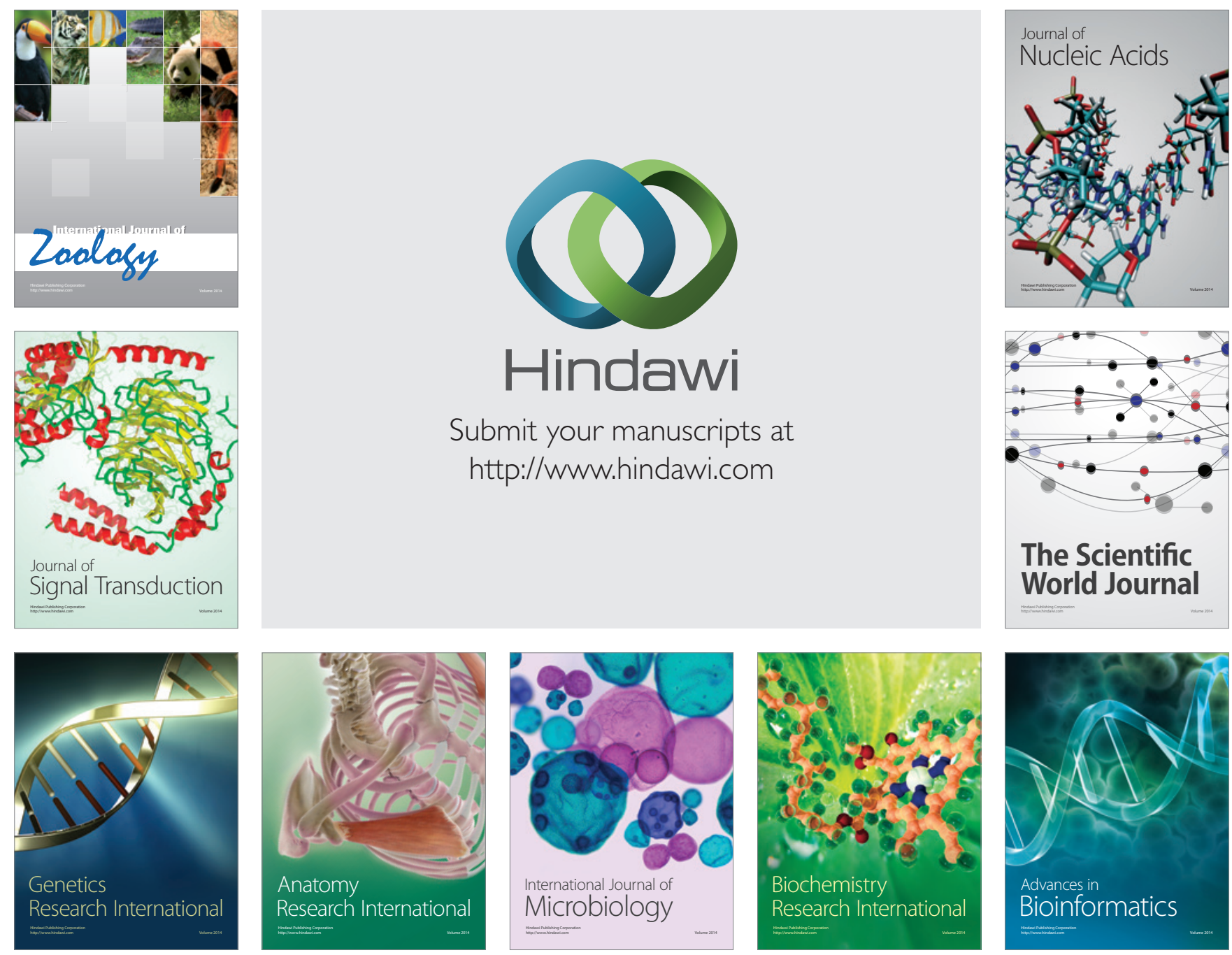

The Scientific World Journal
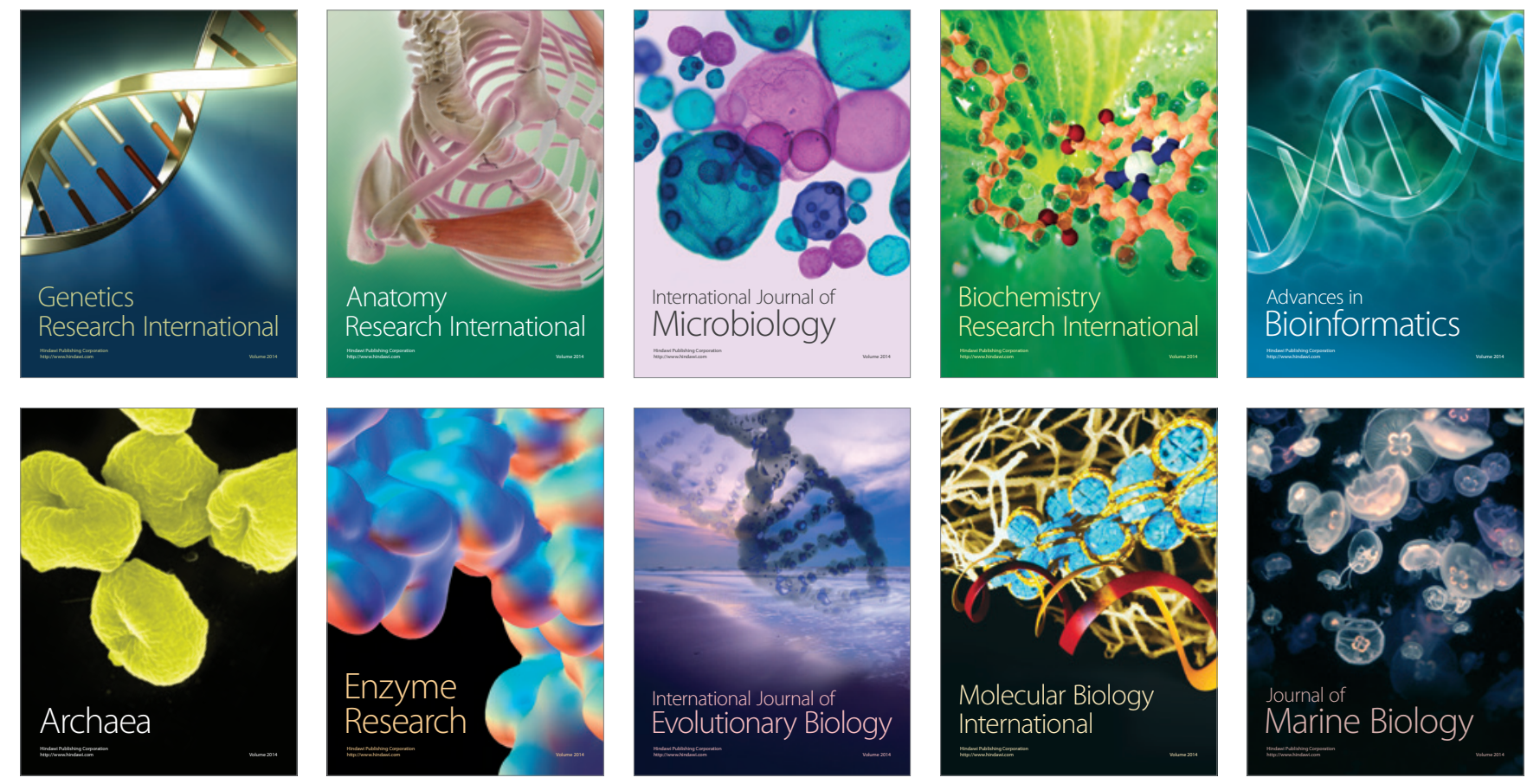